OPEN ACCESS

Edited by:

Muhammad Imran Khan, CECOS University of Information Technology and Emerging Sciences,

Pakistan

Reviewed by:

Sreedevi Upadhyayula, Indian Institute of Technology Delhi,

India

Veera Gnaneswar Gude, Mississippi State University, United States

${ }^{*}$ Correspondence:

Robert S. Weber robert.weber@pnnl.gov

Specialty section: This article was submitted to Sustainable Energy Systems and

Policies,

a section of the journal

Frontiers in Energy Research

Received: 26 August 2021 Accepted: 22 November 2021 Published: 24 December 2021

Citation:

Male JL, Kintner-Meyer MCW and Weber RS (2021) The U.S. Energy

System and the Production of Sustainable Aviation Fuel From

Clean Electricity.

Front. Energy Res. 9:765360. doi: 10.3389/fenrg.2021.765360

\section{The U.S. Energy System and the Production of Sustainable Aviation Fuel From Clean Electricity}

\author{
Jonathan L. Male ${ }^{1,2}$, Michael C. W. Kintner-Meyer ${ }^{1}$ and Robert S. Weber ${ }^{1 *}$ \\ ${ }^{1}$ Pacific Northwest National Laboratory, Bioproducts Institute, Richland, WA, United States, ${ }^{2}$ Biological Systems Engineering \\ Department, Washington State University, Pullman, WA, United States
}

Jet fuel is relatively small in terms of energy consumption and carbon dioxide emissions (10\% of U.S. transportation sector in 2021 , expected to increase to $14 \%$ by 2050). Still airlines have ambitious goals to reduce their greenhouse footprints from carbon-neutral growth beginning this year to reducing greenhouse gas emission for international flights by $50 \%$ by 2050 compared to 2005 levels. The challenge is heightened by the longevity of the current fleet (30-50 years) and by the difficulty in electrifying the future fleet because only $5 \%$ of the commercial aviation greenhouse gas footprint is from regional flights that might, conceivably be electrified using foreseeable technology. Therefore, large amounts of sustainable aviation fuel will be needed to reach the aggressive targets set by airlines. Only 3 million gallons (11.4 ML) of sustainable aviation fuel (SAF) (with a heat of combustion totaling about $400 \mathrm{TJ}=0.0004 \mathrm{EJ}$ ) was produced in the U.S. in 2019 for a 26 billion gallon per year market (3.6 EJ/year). Fischer-Tropsch and ethanol oligomerization (alcohol-to-jet) are considered for producing SAF, including the use of renewable electricity and carbon dioxide. In sequencing the energy transition, cleaning the U.S. grid is an important first step to have the largest greenhouse gas emissions reduction. While carbon dioxide and clean electricity can potentially provide the SAF in the future, an ethanol oligomerization option will require less energy.

Keywords: jet fuel, fischer-tropsch, ethanol oligomerization, electrofuel, energy storage

\section{INTRODUCTION}

Commercial aircraft rely on the combustion of hydrocarbon fuels because they offer high specific energy (energy per unit mass) and high energy density (energy per unit volume). Neither of those flight-critical characteristics can yet be matched by rechargeable power trains consisting of modern batteries or fuel cells and electrical motors in multi-aisle long-haul aircraft. The global aviation sector seeks to reduce greenhouse gas emission for international flights by $50 \%$ by 2050 compared to 2005 levels (IATA, 2009). That ambitious goal will require both the continued development of electrical power trains (primarily for regional travel) and drop-in renewable fuels (for long-haul travel). U.S. airlines have committed to net-zero carbon emissions by 2050 and carbon-neutral growth relative to a 2019 baseline for domestic and international flights (Airlines for America, 2021). In March 2021, the member carriers of Airlines for America (A4A) collectively committed to net-zero carbon emissions by 2050. U.S. airlines improved their fuel efficiency by more than 135 percent between 1978 and year-end 2019, saving over five billion metric tons of carbon dioxide $\left(\mathrm{CO}_{2}\right)$. However, fuel efficiency improvements with petroleum-based fuels cannot move the industry to net-zero emissions 
of $\mathrm{CO}_{2}$. Sustainable aviation fuel (SAF) is needed. Moreover, about $93 \%$ of Global aircraft emissions are from medium- and long-haul flights (International Council on Clean Transportation., 2019). Therefore, addressing the bulk of the emissions requires a long -haul solution, which, from now through 2050, will mean the introduction and use of SAFs.

This paper considers the problem from an energy perspective and does not consider all routes that might contribute to the practical solution of GHG reduction in the transportation sector. The routes that are considered produce fuels that already have ASTM approval for aviation use. The energy analysis provides insights for implementation. The analysis is novel in that it considers the aviation sector in the context of a deliberate pathway to overall reduction in greenhouse gases. In particular, we have included a discussion entitled "Positioning SAF in a sequence of options for making the transportation sector more sustainable."

Here we will consider routes to renewable fuels, starting with renewable or waste sources of carbon and noncarbogenic sources of energy. Noncarbogenic sources include both renewable energy (e.g., biomass, solar, wind), hydropower, and nuclear energy. To compare different sources of energy more easily, it is useful to express supply and demand in a common unit. Here we have chosen to use the SI unit of exajoule $\left(10^{18} \mathrm{~J}\right)$, which is approximately 1 Quad $(=1$ quadrillion BTU). As a reference, consider that the U.S. uses about 100 EJ per year, about $3.5 \%$ of which serves the airline industry as fuel and $25 \%$ serves other modes of transportation (Holladay et al., 2020).

We will express power (energy per time) in Watts $(1 \mathrm{~W}=1 \mathrm{~J} /$ s). Therefore, the roughly $3.6 \mathrm{EJ} /$ year employed by the aviation sector, $P_{\text {aviation, }}$ averaged across a year, is equivalent to the continuous consumption of more than $100 \mathrm{GW}$ of power:

$$
P_{\text {aviation }}=\frac{3.6 \mathrm{EJ}}{\text { year }} \times \frac{1 \text { year }}{31.5 \times 10^{6} \mathrm{~s}}=114 \mathrm{GW}
$$

To further exemplify the units, consider that 1 barrel (159 L) of oil or jet fuel has an enthalpy of combustion of about 6 GJ. Finally, in this litany of conversions, note that the usual unit for expressing electrical energy, the Watt-hour, is equal to $3.6 \mathrm{~kJ}$, so $1 \mathrm{TW}$-hour $(1$ trillion Wh $)=0.0036 \mathrm{EJ}$.

Many countries are considering the use of renewable electricity, coupled with low carbon intensity hydrogen to produce synthetic fuels from $\mathrm{CO}_{2}$ and other carbon waste streams. Such an approach requires a tremendous amount of renewable electricity that is not yet available. For example, in 2020 the United States generated about $14.5 \mathrm{EJ}$ $(3,884 \mathrm{TWh})$ of electricity of which only $5.4 \mathrm{EJ}(1,620 \mathrm{TWh}=$ $0.17 \mathrm{GW}$ ) was from renewables or noncarbogenic sources (U.S. Energy Information Administration, 2021a). Waste carbon that contains energy is an important carbon resource. Waste carbon containing energy includes industrial waste gas, municipal solid waste, agricultural and forestry residues, unrecyclable plastic, manures, and municipal wastewater sludge. For this paper, we will focus mainly on the energy requirements for converting $\mathrm{CO}_{2}$ to jet fuel.

As will be shown below, thermodynamics combined with inefficiencies in the electrochemical conversions mean that every Joule of jet fuel produced electrolytically from $\mathrm{CO}_{2}$ will require the input of $2-3 \mathrm{~J}$ of noncarbogenic electricity. Using waste inputs with negative heats of combustion (e.g., CO, digester methane, manure) would decrease the input of electrical energy but those materials are not available in amounts commensurate with the production of jet fuel. Therefore, on the order of $10 \mathrm{EJ} /$ year $(=317 \mathrm{GW})$ of new clean electricity generation will be needed to accommodate the generation of current and future levels of demand for aviation fuel.

The mismatch between available, carbon-free electricity and the amount needed for providing clean synthetic fuels reinforces the importance of improving the efficiency of all phases of fuel production, including production of hydrogen. As synthetic fuel technologies scale, in addition to the need for new electric generation, there is a need for additional electric energy storage to buffer momentary, diurnal, and seasonal fluctuations in supply. Finally, if we focus solely on the transportation system, we may miss impacts on reducing $\mathrm{CO}_{2}$ from the entire system that would be gained by a sequencing of energy transitions.

Because we will be considering the possibility of substituting fossil fuels with fuels produced from environmentally cleaner sources, it is interesting to compare that amount of power with the total installed capacity in the U.S. electricity generating sector, which is about $1100 \mathrm{GW}$ (U.S. Energy Information Administration, 2021a), of which a total of $376 \mathrm{GW}(=12 \mathrm{EJ} /$ year) is produced noncarbogenically from nuclear ( $92 \mathrm{GW}$ of capacity) plus renewables (284 GW of capacity).

Because we will be considering chemical conversions of different feedstocks into aviation fuel, it is convenient to specify a simplified surrogate for the multicomponent mixture that is actual jet fuel. We have selected to use dodecane, $n-\mathrm{C}_{12} \mathrm{H}_{26}$, which has molecular weight of $170 \mathrm{~g} / \mathrm{mol}$. Its heat of combustion, about $8 \mathrm{MJ} / \mathrm{mol}=46.5 \mathrm{MJ} / \mathrm{kg}$, is about $8 \%$ higher than that of JetA1 $(43 \mathrm{MJ} / \mathrm{kg})$. Therefore, the aviation sector's typical consumption of $3.6 \mathrm{EJ} /$ year of primary energy in the U.S. would correspond to the use of $0.46 \mathrm{Tmol} / \mathrm{y}$ of a dodecane-like molecule $=26.8 \mathrm{billion}$ gal/year versus $26.7 \mathrm{billion}$ gal/year of actual jet fuel (U.S. Energy Information Administration, 2020). Recall that 1 Teramol $=10^{12} \mathrm{~mol} ; 1 \mathrm{Mt}=1$ megaton $=109 \mathrm{~kg}$, and the density of both dodecane and Jet-A1 are about $0.8 \mathrm{~kg} / \mathrm{L}$ ).

Here, we provide estimates for three aspects of producing sustainable aviation fuels: 1) size of the problem, 2) synthetic routes and their material and energy inputs, and 3) a sequence of options that affords significant greenhouse gas savings for the entire economy, including the aviation sector. We discuss the issues from a U.S.-centric perspective, but we note that the underlying science and technology required to address those issues should be generally applicable.

\section{SIZE OF THE PROBLEM}

Even though the amount of fuel used by U.S. air traffic each year is only $12.5 \%(3.6 \mathrm{EJ} /$ year $)$ of that consumed by the entire transportation sector in the U.S. (Figure 1), replacing the fossilsource energy with renewable resources would impose significant additional demands on the national electric infrastructure, of at least $1,000 \mathrm{TWh} /$ year (= 3.6 EJ/year), which is about $62 \%$ of the current 

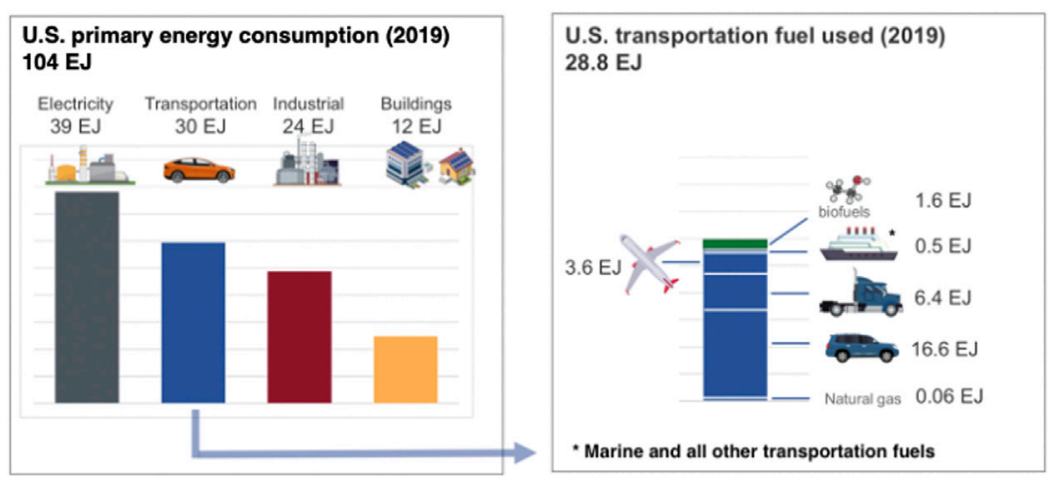

FIGURE 1 | Primary energy input into U.S. sectors (U.S. Energy Information Administration, 2019). Discrepancies in some of the numbers arise from rounding errors.
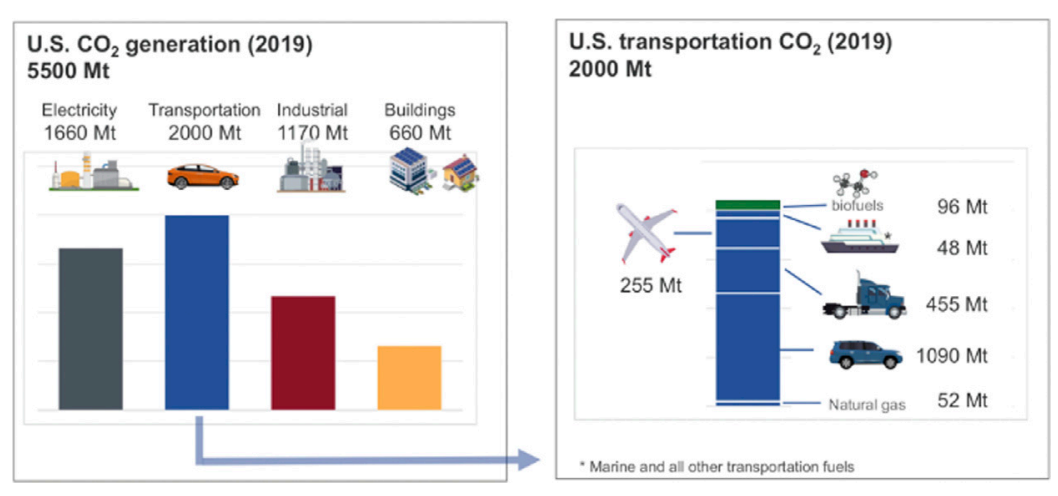

FIGURE 2 | Carbon dioxide emissions from U.S. sectors.

noncarbogenic generation. The fraction of carbon dioxide emitted by the sector is proportional to its use of fuel ( $12.8 \%$, Figure 2$)$, which is not surprising, given the similarity in heating values, compositions, and energy efficiencies of the conversion of transportation fuels. The inference is that aviation is neither an especially large nor unduly onerous part of the overall problem of reducing carbon emissions from transportation. So, without detracting from the goal of the aviation sector to reduce its emissions of carbon dioxide by $50 \%$ over the next 29 years, a rational, global approach to reducing emissions of carbon dioxide should sequence the steps towards ameliorating $\mathrm{CO}_{2}$ emissions in an order that takes the biggest, cheapest steps as early as possible and that prepares the energy infrastructure for the subsequent changes. We will discuss those points further at the end of this article.

\section{SYNTHETIC ROUTES}

The thermodynamic constraint on producing renewable fuels-conservation of energy-plus the stoichiometry of a process set lower limits on the amount of renewable energy and renewable material that must be input into the production process to meet the decarbonization goals of the aviation sector.
The actual amount of input energy and material will depend on the efficiency and selectivity of the selected process. Here we consider three illustrative routes to Sustainable Aviation Fuel (SAF): 1) Fischer-Tropsch chemistry employing gasification of biomass (de Klerk, 2016); 2) Fischer-Tropsch chemistry employing electrochemically produced synthesis gas, for example (Albert et al., 2016); and 3) oligomerization of ethanol (Brooks et al., 2016). The source of the ethanol in the third case could be either the standard fermentation of sugars (McAloon et al., 2000) or the newer LanzaTech process that ferments $\mathrm{CO}, \mathrm{CO}_{2}$ and $\mathrm{H}_{2}$ found in industrial waste gas (Handler et al., 2015). Other approaches have been discussed (Brooks et al., 2016; Hannula et al., 2020), but those three serve to illustrate the magnitude of the challenges of accessing sufficient lower carbon intensity energy and renewable carbon. Renewable carbon is defined here as biomass and waste streams, be they solid, liquid, or gas, that are recycled at a molecular level.

\subsection{Fischer-Tropsch Process Using Renewable Carbon}

The Fischer-Tropsch (FT) process combines synthesis gas, $\mathrm{H}_{2}$ plus $\mathrm{CO}$, to make mostly straight chain hydrocarbons (Dry, 
2004). The oxygen from the CO converts mainly into water but some oxygenated hydrocarbons can be produced as well. The process has been practiced since the Second World War, primarily using fossil fuels (coal, natural gas) as the source of input carbon, and process heat. The synthesis gas is fed to the Fischer-Tropsch reactor at high pressure and high temperature ( $\sim 500 \mathrm{~K}, \sim 25 \mathrm{bar})$. Production of intermediate synthesis gas decouples the downstream fuel-synthesis process from the feedstock. Therefore, the Fischer-Tropsch reaction can meet ASTM D7566 specification for aviation fuel (ASTM International, 2021) from any source of synthesis gas, including renewable feedstocks (de Klerk, 2016).

The process makes steam and a broad distribution of hydrocarbons that must be separated and upgraded (e.g., hydrocracked) to make jet-range fuel, i.e., our nominal fuel surrogate:

$$
\begin{gathered}
12 \mathrm{CO}+25 \mathrm{H}_{2}+\rightarrow \mathrm{C}_{12} \mathrm{H}_{26}+12 \mathrm{H}_{2} \mathrm{O} \\
\Delta \mathrm{G}^{0}=-1,684.9 \mathrm{~kJ} / \mathrm{mol}
\end{gathered}
$$

Reaction 1

The FT process does make fuel molecules heavier than jet fuel, which might be hydrocracked into the jet range, however, we have ignored them in this first order analysis because their conversion into jet fuel will require additional hydrogen (Ostadi et al., 2019), which will only add to their cost. Selling those products as ultralow sulfur diesel fuel could lower the selling price of the jet fuel but, obviously, would then not directly increase the supply of jet fuel.

The process is approximately $50 \%$ carbon efficient (jet-fuel carbon produced/carbon input) (de Klerk, 2016; Gruber et al., 2019) and about 50\% energy efficient (heating value of jet-fuel/ heating value of biomass input) when the synthesis gas is produced by autothermal gasification of a biomass feedstock (Zhang et al., 2011; Ostadi et al., 2019). The gasification is illustrated simplistically by Reaction 2 . The feedstock in Reaction 2 was assumed to have the elemental composition and heat of combustion of a soft wood such as pine; agricultural wastes contain more oxygen and have an enthalpy of combustion value closer to $15 \mathrm{MJ} / \mathrm{kg}$ (Hazel and Bardon, 2008)).

$$
\begin{gathered}
\mathrm{CH}_{4.8} \mathrm{O}_{2.1}+0.55 \mathrm{O}_{2} \rightarrow \mathrm{CO}+2.4 \mathrm{H}_{2} \\
\Delta \mathrm{H}_{\text {reaction }}=-153 \mathrm{~kJ} / \mathrm{mol}
\end{gathered}
$$

Reaction 2

The carbon that is not converted to fuel or fuel precursors (e.g., tars that form) can be burned elsewhere in the process to generate heat. In Reaction 2 as written, the heating value of the "wood" $-1,017 \mathrm{~kJ} / \mathrm{mol}$ is converted into synthesis gas whose heat of combustion is about $-860 \mathrm{~kJ} / \mathrm{mol}$, so a loss of about $15 \%$ of the input energy before consideration of any other sinks for the energy of the feedstock (e.g., compression, reaction selectivity). We note that steam reforming of the wood would produce the $\mathrm{CO}$ endothermically and autothermal reforming can be configured to be thermoneutral, but those conversions do not produce synthesis gas with the correct stoichiometry for Fischer Tropsch synthesis.

The process requires about twice the amount of input energy than reports to the fuel. Autothermal gasification of biomass is about $65-75 \%$ carbon efficient (Zhang et al., 2011). So, even if the FT process were $70 \%$ carbon efficient to making jet range fuels (it is actually closer to $50 \%$ carbon efficient (Gruber et al., 2019)), starting with biomass yields no more than a 50\% overall carbon efficiency. Heavier (diesel-range, wax products) will require additional processing that will cost money. Selling those products might help offset the price of the SAF but won't directly increase its supply. Because the heating value of lignocellulosic biomass is about $15-20 \mathrm{MJ} / \mathrm{kg}$ (Hazel and Bardon, 2008), making a year's supply of jet fuel, 3.6 EJ, would require the input of about $480 \mathrm{Mt}$ of biomass $(=2 \times 3.6 \mathrm{EJ} \div$ $15 \mathrm{MJ} / \mathrm{kg}$ ). The long-term base-case of the updated Billion Ton Study (U.S. Department of Energy, 2016) comprises $826 \mathrm{Mt} /$ year of biomass. So, more than half of the potentially available biomass-derived fuel feedstock would need to be devoted to jet fuel if the latter were produced by a process that involved production of the synthesis gas from the biomass.

In one estimate for a plant fed with coal (Reed et al., 2007), the production of 50,000 bbl/day of liquid fuel, was accompanied by an export of $125 \mathrm{MW}$ of electricity. In that case, the net exportable electrical energy amounts to more than 10-times the energy resident in the liquid fuel:

$$
\begin{aligned}
\frac{E_{\text {export }}}{E_{\text {fuel }}} & =\frac{125 \mathrm{MW}}{50000 \mathrm{bbl} / \text { day }} \\
& =\frac{125 \mathrm{MJ} / \mathrm{s}}{50000 \mathrm{bbl} / \text { day } \times 6.1 \mathrm{GJ} / \mathrm{bbl}} \times \frac{31.5 \times 10^{6} \mathrm{~s}}{1 \text { day }}=12.9
\end{aligned}
$$

That large ratio reflects the exothermicity of Reaction 1 plus recovery of process heat generated from the partial oxidation of about half the feedstock to produce the synthesis gas. The estimate is germane also to thermal gasification of biomass (Shahabuddin et al., 2020), where it represents both an opportunity (generation of renewable electricity) and a problem (low carbon yield of fuel) that could be balanced against each other according to higher-level optimization criteria (Tock et al., 2010).

\subsection{Fischer-Tropsch Process Using Renewable Carbon and Renewable Energy}

If, instead, the energy for producing the synthesis gas could be added directly from renewable sources to renewable materials (Samavati et al., 2018; Gruber et al., 2019; Hannula et al., 2020; Korberg et al., 2021), then the overall process could, in principle, be much more carbon and energy efficient.

For example, concentrated $\mathrm{CO}_{2}$, perhaps from an ethanol refinery or from the recycle stream in a $\mathrm{CO}_{2}$-fed FischerTropsch process (Hannula et al., 2020), could be converted into carbon monoxide, $\mathrm{CO}$, using renewable electricity (Reaction 3, potentials referenced to the reversible hydrogen electrode (Kortlever et al., 2015)):

$$
\begin{array}{r}
\mathrm{CO}_{2} \rightarrow \mathrm{CO}+1 / 2 \mathrm{O}_{2} \mathrm{E}^{0}=-1.33 \mathrm{~V}, \Delta \mathrm{G}^{0}=257.1 \mathrm{~kJ} / \mathrm{mol} \\
\text { Reaction } 3
\end{array}
$$

Similarly, $\mathrm{H}_{2}$ could be produced by electrolysis of water (Reaction 4): 


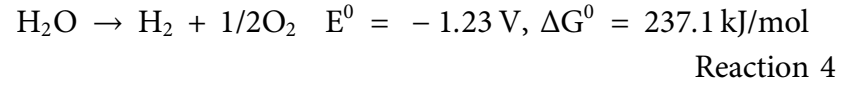

Just making sufficient $\mathrm{CO}$ and $\mathrm{H}_{2}$ from $\mathrm{CO}_{2}$ and $\mathrm{H}_{2} \mathrm{O}$ to synthesize dodecane would require a minimum input energy, $\Delta G_{m i n}$, that can be calculated from the stoichiometry of Reaction 1:

$$
\begin{aligned}
\Delta G_{\min } & =12 \times 257.1 \mathrm{~kJ} / \mathrm{mol}+25 \times 237.1 \mathrm{~kJ} / \mathrm{mol} \\
& =9.0 \mathrm{MJ} / \mathrm{mol}_{\text {dodecane }}
\end{aligned}
$$

To perform the reaction practically, however, that energy must be increased, slightly, by the work required to compress the gas to process conditions (about $20 \mathrm{~kJ} / \mathrm{mol}=\mathrm{RT} \ln (25 \mathrm{bar} / 1 \mathrm{bar})$ ) and, significantly, to overcome activation barriers of the constituent reactions. The practical electrochemical overpotentials for Reactions 3, 4 are each about $0.6 \mathrm{~V}$ (Rakowski-Dubois and Dubois, 2009), so the practical input energies must be increased by about $50 \%$ to $\sim 2 \mathrm{~V}$ and $1.8 \mathrm{~V}$ respectively. The process would still be only about $50 \%$ efficient towards the production of jet-range fuel (because of the broad distribution of products in the Fischer Tropsch process. Multiplying $\Delta G_{\min }$ by 1.5 and doubling $M_{\mathrm{min}}$, the mass of carbon incorporated in the fuel, represent reasonable lower bounds on the renewable energy and renewable carbon required to generate aviation fuel by this route. The inefficient utilization of the feedstock, however, means that the practical energy input, $1.5 \times 9.0 \mathrm{MJ} / \mathrm{mol}=13.5 \mathrm{MJ} / \mathrm{mol}$, must also be doubled to adjust for the extra feedstock. Therefore, the adjusted, practical energy input, $\Delta G_{\text {practical }}$ will be $2 \times 13.5 \mathrm{MJ} /$ $\mathrm{mol}=27 \mathrm{MJ} / \mathrm{mol}$, which is the reason that we stated above that $\gtrsim 2 \mathrm{~J}$ of input energy is needed for every $1 \mathrm{~J}$ of SAF.

The enthalpy of combustion of dodecane (and jet fuel) is about $8 \mathrm{MJ} / \mathrm{mol}$. Therefore, this route would use approximately $27 \mathrm{MJ} / \mathrm{mol}$ of energy (from the biomass, electrical power, and other inputs) to make $8 \mathrm{MJ} / \mathrm{mol}$ worth of jet fuel. Given that this "electrofuel" would be intended for use in a jet engine whose efficiency would be around $40 \%$ (National Academies of Sciences E and Medicine., 2016), the $27 \mathrm{MJ} / \mathrm{mol}$ of input energy would result in $\sim 3 \mathrm{MJ} / \mathrm{mol}$ of work, a significant degradation that argues for the direct use, where possible of the input electrical energy. As discussed above, however, direct electrification of the propulsion of aircraft cannot yet achieve the desired range of travel. Therefore, we next discuss another route to sustainable aviation fuel that promises to be more energy- and mass-frugal.

\subsection{Oligomerization of Ethanol ex Cellulose}

Both methanol and ethanol can be oligomerized to make fuel range hydrocarbons. The methanol-to-gasoline process invented by ExxonMobil in the 1970s (Chang, 2007; Gogate, 2019) produces, using a small pore zeolite as the conversion catalyst, an unsaturated liquid (olefins, aromatics). The unsaturated intermediate can be hydrogenated to make a liquid fuel fungible with petroleum-derived gasoline. Similarly, ethanol can be converted into gasoline-range molecules through a homologous intermediate. However, ethanol also offers other chemistries (e.g., dehydration to the olefin, Guerbet reaction), that provide effective routes to the heavier molecules that comprise aviation fuel (Brooks et al., 2016).

The source of the ethanol is nearly irrelevant to its downstream conversion into jet fuel (Handler et al., 2015). There are, however, life-cycle differences among the different feedstocks (ethanol from fermentation of sugars derived from biomass, ethanol from waste industrial gas, ethanol from landfill gas). Roughly, the savings in greenhouse gases for each feedstock vary inversely with the cost of the feedstock (Table $\mathbf{1}$ ).

Those feedstock costs should be compared to the wholesale price of jet fuel, which recently (U.S. Energy Information Administration, 2020) has averaged close to $1.80 \mathrm{USD} / \mathrm{gal}$ (= 13.8 USD/GJ). The difference between the feedstock cost and the wholesale price is the amount available for operating costs and amortized capital costs and profit. Despite the low feedstock price of corn stover, it has not played a large role in the production of fuel ethanol, because of the still challenging conversion of cellulose into ethanol (Lamers et al., 2021).

The currently unused amount of potentially available, lignocellulosic feedstocks presented in Table $\mathbf{1}$ has been estimated to be $826 \mathrm{Mt}$ /year in the long term (2040), base case scenario of the Billion Ton Study (U.S. Department of Energy, 2016). That material is composed primarily of sugars, e.g., $\mathrm{C}_{6} \mathrm{H}_{12} \mathrm{O}_{6}$, which have a molecular weight of $180 \mathrm{~g} / \mathrm{mol}$, and lignin (roughly $2 / 3$ of the waste cellulosic feedstock is polysaccharides). The sugar provides the carbon that goes into the growing cells and the product fuel. Usually, the lignin is just burned for process heat (e.g., for distillation). That amount of material would be sufficient to make $0.40 \mathrm{Tmol} / \mathrm{year}$ of our surrogate, paraffinic fuel, $\mathrm{C}_{12} \mathrm{H}_{26}$, if it could be made by fermenting the sugars, $\mathrm{C}_{6} \mathrm{H}_{12} \mathrm{O}_{6}$, into ethanol followed by oligomerization of the ethanol (3 sugar molecules per fuel molecule):

$$
\begin{array}{cc}
\mathrm{C}_{6} \mathrm{H}_{12} \mathrm{O}_{6} \rightarrow 2 \mathrm{C}_{2} \mathrm{H}_{5} \mathrm{OH}+2 \mathrm{CO}_{2} & \text { Reaction } 5 \\
6 \mathrm{CH}_{3} \mathrm{CH}_{2} \mathrm{OH}+\mathrm{H}_{2} \rightarrow \mathrm{C}_{12} \mathrm{H}_{26}+6 \mathrm{H}_{2} \mathrm{O} & \text { Reaction } 6 \\
826 \mathrm{MT}_{\text {biomass }} / \text { year } \times \frac{2 \mathrm{t}_{\text {sugar }}}{3 \mathrm{t}_{\text {biomass }}} \times \frac{10^{9} \mathrm{~kg}}{\mathrm{Mt}} \times \frac{1 \mathrm{~mol}_{\text {sugar }}}{0.18 \mathrm{~kg}} \frac{1 \mathrm{~mol}_{\text {fuel }}}{3 \mathrm{~mol}_{\text {sugar }}} \\
=1 \mathrm{Tmol}_{\text {fuel }} / \text { year }
\end{array}
$$

Recall from the introduction that the U.S. uses "only" 0.46 Tmol of jet fuel, therefore, in principle there could be enough feedstock to satisfy this route. However, there are mass inefficiencies in both the fermentation process $(72 \%$ in one study of making ethanol from wood (Zhu et al., 2010)) and the oligomerization process ( $75 \%$ carbon efficient to jet fuel and $\sim 90 \%$ to jet fuel plus diesel-range fuel in one patent (Lilga et al., 2017). The concatenation of those inefficiencies implies that more than the projected, currently unused supply of lignocellulosic feedstocks would be needed to satisfy the U.S. consumption of jet fuel.

\subsection{Oligomerization of Ethanol ex Waste Gas}

A similar calculation can be made for a route that starts with $\mathrm{CO}$ that is produced by the steel industry. In steel making, the U.S. uses about $0.39 \mathrm{EJ}$ worth of metallurgical coke as a reagent (i.e., not as a fuel) (U.S. Energy Information Administration, 2021e). The heating value 
TABLE 1 | Comparison of lifecycle analyses and feedstock costs for ethanol-derived SAF.

\begin{tabular}{|c|c|c|c|}
\hline Source of ethanol & $\begin{array}{c}\text { Lifecycle decrease in } \\
\text { greenhouse gas } \\
\text { emissions } \\
(\%)\end{array}$ & $\begin{array}{l}\text { Feedstock cost/ } \\
\text { USD GJ }\end{array}$ & Comment and References \\
\hline $\begin{array}{l}\mathrm{CO} \text { (steelmaking: } \mathrm{FeO}_{x}+x \mathrm{C} \rightarrow \\
\mathrm{Fe}+x \mathrm{CO})\end{array}$ & 67 & 2.5 & $\begin{array}{l}\text { Cost of CO assumed to be } \$ 25 / \text { ton which makes its energy cost approximately } \\
\text { equal to that of natural gas at } 2.5 \$ \text { MMBTU Markets Insider (2021) }\end{array}$ \\
\hline $\begin{array}{l}\text { Lignocellulosic farm waste (e.g., corn } \\
\text { stover) }\end{array}$ & 92 & 2.3 & Graham et al. (2007) \\
\hline Forestry Lignocellulosics & 98 & 8.5 & $\begin{array}{l}\text { Averaged ranges (Martinkus et al., 2017) supplied at a rate sufficient to for a } \\
\text { biorefinery }\end{array}$ \\
\hline $\begin{array}{l}\text { Lignocellulosic product/energy crop } \\
\text { (e.g., switchgrass) }\end{array}$ & 88 & 7.5 & Agricultural Marketing Resource Center (2018) \\
\hline
\end{tabular}

of that coke is approximately that of pure carbon, $394 \mathrm{~kJ} / \mathrm{mol} \mathrm{so}$, in the U.S., the manufacture of steel (110 Mt/year, (U.S. Geological Survey, 2020)) could produce approximately 1 Tmol of CO (Eq. 5). A small fraction of the carbon is incorporated into the metal, $<0.5 \mathrm{wt} \%$ (MIT Department of Civil and Environmental Engineering, 1999) (Eq. 6):

$$
\begin{gathered}
n_{\mathrm{CO}}=\frac{0.39 \mathrm{EJ}}{394 \mathrm{~kJ} / \mathrm{mol}_{\mathrm{C}}}=1 \mathrm{Tmol}_{\mathrm{C}} \times \frac{1 \mathrm{~mol}_{\mathrm{CO}}}{\mathrm{mol}_{\mathrm{C}}} \\
n_{\text {incorporated }}=0.5 \mathrm{wt} \% \times 110 \mathrm{Mt} / \text { year } \div 0.012 \mathrm{~kg} / \mathrm{mol}=46 \mathrm{Gmol}
\end{gathered}
$$

In the LanzaTech process the microbes use CO for energy and as a carbon source in a metabolic process that, formally, is equivalent to water-gas shift. Without suggesting the actual biochemical mechanisms, the overall stoichiometry for converting $\mathrm{CO}$ into $\mathrm{C}_{12} \mathrm{H}_{26}$, our surrogate for jet fuel is, minimally:

$$
\begin{aligned}
& 6 \mathrm{CO}+3 \mathrm{H}_{2} \mathrm{O} \rightarrow \mathrm{CH}_{3} \mathrm{CH}_{2} \mathrm{OH}+4 \mathrm{CO}_{2} \\
& \Delta \mathrm{G}_{\text {reaction }}=-216 \mathrm{~kJ} / \mathrm{mol}
\end{aligned}
$$

Combining Reaction 7 with Reaction 6 (ethanol oligomerization which, again, is about $75 \%$ efficient towards jet range products) implies that the $1 \mathrm{Tmol}$ of $\mathrm{CO}$ possibly available from the U.S. steel industry could make, $1 \mathrm{Tmol}_{\mathrm{CO}} \times$ $1 \mathrm{~mol}_{\text {dodecane }} / 36 \mathrm{~mol}_{\mathrm{CO}} \times 0.75=21 \mathrm{Gmol}$ of jet fuel and thus satisfy only about $5 \%$ of the U.S. demand ( $0.45 \mathrm{Tmol} / \mathrm{year})$. Gas from a partial combustion fluidized catalytic cracking units in refineries could be a significant source of additional CO (U.S. Environmental Protection Agency, 2010) but we do not have a ready estimate of the available annual flow rates nor of the amenability of refineries to alter their operations to divert such streams away from their usual utility as fuel gas (Babcock and Wilcox Company, 2015).

\subsection{Oligomerization of Ethanol ex Waste $\mathrm{CO}_{2}$}

Other, carbon-containing waste gases (e.g., from ethanol fermentation, refining, landfill, wastewater treatment) might also be considered as an input to this process. For example, $\mathrm{CO}$ and $\mathrm{H}_{2}$ could be sourced electrochemically as discussed above in Section 3.2. In that case, the energy balance and carbon balance will depend on the specific stoichiometry of the inlet synthesis gas (Table 2).

Ethanol production, $\sim 16$ billion gal/year in the U.S. (U.S. Energy Information Administration, 2021c), produces about $46 \mathrm{Mt} /$ year of $\mathrm{CO}_{2}\left(\approx 1.04 \mathrm{Tmol}_{\mathrm{CO}_{2}}\right)$. Consider converting all the carbon dioxide produced by the fermentation of ethanol into a sustainable aviation fuel by a three-step process. In the envisioned process, first, make the synthesis gas electrochemically (Reaction 3), then employ fermentation to convert that synthesis gas into ethanol (Reaction 5), and finally oligomerize the waste gas-derived ethanol to make jet fuel (Reaction 6). The energy input per mol of fuel would be derived from Reaction 3 (electrolysis of $\mathrm{CO}_{2}$ to make $\mathrm{CO}$ ) and the stoichiometries (and carbon efficiencies) of Reactions 5, 6. This route might satisfy $4.7 \%$ of the U.S. demand for jet fuel but would require inputting $19 \mathrm{EJ} /$ year of renewable electricity or 3.6 times the amount of noncarbogenic electricity currently produced in the U.S. (see the Excel worksheet in the Supplemental Information for the detailed calculation).

The quantity of fuel produced can be increased and the electrical input can be decreased by adding $\mathrm{H}_{2}$ to the feed to the $\mathrm{CO}$ fermenter. The addition of external $\mathrm{H}_{2}$ provides a new energy source for the organism, allowing nearly all the carbon to be shunted into ethanol (Reaction 8). A minor portion of carbon will go to producing biomass:

$$
\begin{aligned}
2 \mathrm{CO}+4 \mathrm{H}_{2} & \rightarrow \mathrm{CH}_{3} \mathrm{CH}_{2} \mathrm{OH}+\mathrm{H}_{2} \mathrm{O} \\
\Delta \mathrm{G}_{\text {reaction }} & =-135 \mathrm{~kJ} / \mathrm{mol}
\end{aligned}
$$

Reaction 8

Combining Reaction 8 with Reaction 6 (ethanol oligomerization) yields an overall stoichiometric ratio of 12 $\mathrm{CO}$ and $24 \mathrm{H}_{2}$ per nominal dodecane instead of 12 and 25 respectively. Therefore, the minimum electrical energy required for the electrolysis will be nearly the same as before (Eq. 3), which still must be multiplied by 1.5 owing to the overpotentials for the two electrolyses. There will also still be a penalty owing to the selectivity of the oligomerization 
TABLE 2 | Summary of inputs for making jet fuel from renewable or waste $\mathrm{CO}_{2}$.

\begin{tabular}{|c|c|c|c|c|c|}
\hline Feedstock & Notional stoichiometry & $\begin{array}{l}\text { Carbon } \\
\text { yield }\end{array}$ & $\begin{array}{c}\text { Energy } \\
\text { yield (LHV) }\end{array}$ & $\begin{array}{l}\mathrm{J}(\%) \text { et fuel/U.S. } \\
\text { demand }(\%)\end{array}$ & $\begin{array}{l}\text { Practical electricity } \\
\text { input }\end{array}$ \\
\hline $\begin{array}{l}\text { CO fermentation from } 16 \text { billion gal } \text { Ethanol }_{\text {year }}{ }^{-1}= \\
\text { fermenter } \mathrm{CO}_{2}(46 \mathrm{Mt} / \text { year })^{\mathrm{a}}\end{array}$ & $\begin{array}{l}\mathrm{CO}_{2} \rightarrow \mathrm{CO}+1 / 2 \mathrm{O}_{2} \\
6 \mathrm{CO}+3 \mathrm{H}_{2} \mathrm{O} \rightarrow \mathrm{C}_{2} \mathrm{H}_{5} \mathrm{OH}+ \\
4 \mathrm{CO}_{2} \\
6 \mathrm{C}_{2} \mathrm{H}_{5} \mathrm{OH} \rightarrow \mathrm{C}_{12} \mathrm{H}_{26}+6 \mathrm{H}_{2} \mathrm{O}\end{array}$ & $\begin{array}{l}100 \% \\
33 \% \\
75 \%\end{array}$ & $\begin{array}{l}67 \\
73\end{array}$ & 4.4 & 19 EJ/year \\
\hline $\begin{array}{l}\text { Fermentation of } \mathrm{CO}+\mathrm{H}_{2} \text { from } 16 \text { billion gal } \mathrm{E}_{\mathrm{Ethanol}} / \\
\text { year }^{-1}=\left(46 \mathrm{Mt}_{\mathrm{CO}_{2}} / \text { year }^{\mathrm{a}}\right.\end{array}$ & $\begin{array}{l}3 \mathrm{CO}_{2} \rightarrow 3 \mathrm{CO}+1.5 \mathrm{O}_{2} \\
3 \mathrm{H}_{2} \mathrm{O} \rightarrow 3 \mathrm{H}_{2}+1.5 \mathrm{O}_{2} \\
2 \mathrm{CO}+4 \mathrm{H}_{2} \rightarrow \mathrm{C}_{2} \mathrm{H}_{5} \mathrm{OH}+\mathrm{H}_{2} \mathrm{O} \\
6 \mathrm{C}_{2} \mathrm{H}_{5} \mathrm{OH}+\mathrm{H}_{2} \rightarrow \mathrm{C}_{12} \mathrm{H}_{26}+ \\
6 \mathrm{H}_{2} \mathrm{O}\end{array}$ & $\begin{array}{c}100 \% \\
- \\
100 \% \\
75 \%\end{array}$ & $\begin{array}{l}67 \\
67 \\
81\end{array}$ & 13 & 17 EJ/year \\
\hline $\begin{array}{l}\text { Fermentation of } \mathrm{CO}_{2}+\mathrm{CO}+\mathrm{H}_{2} \text { fermentation from } \\
180 \mathrm{Mt} / \text { year refinery } \mathrm{CO}_{2}^{\mathrm{b}}\end{array}$ & $\begin{array}{l}\mathrm{CO}_{2} \rightarrow \mathrm{CO}+1 / 2 \mathrm{O}_{2} \\
\mathrm{H}_{2} \mathrm{O} \rightarrow \mathrm{H}_{2}+1 / 2 \mathrm{O}_{2} \\
\mathrm{CO}_{2}+\mathrm{CO}+5 \mathrm{H}_{2} \rightarrow \mathrm{C}_{2} \mathrm{H}_{5} \mathrm{OH} \\
+2 \mathrm{H}_{2} \mathrm{O} \\
6 \mathrm{C}_{2} \mathrm{H}_{5} \mathrm{OH}+\mathrm{H}_{2} \rightarrow \mathrm{C}_{12} \mathrm{H}_{26}+ \\
6 \mathrm{H}_{2} \mathrm{O}\end{array}$ & $\begin{array}{l}100 \% \\
100 \% \\
100 \% \\
75 \%\end{array}$ & $\begin{array}{l}67 \\
67 \\
83\end{array}$ & 55 & 53 EJ/year \\
\hline
\end{tabular}

${ }^{a}$ Calculated from the U.S., production of 16 billion gallons/year of ethanol; CO, fermentation efficiencies from (Kopke and Simpson, 2020; Green Car Congress, 2021).

${ }^{b}$ Amount of $\mathrm{CO}_{2}$ from (U.S., Environmental Protection Agency, 2020); CO, fermentation efficiencies from (Kopke and Simpson, 2020).

process (Lilga et al., 2017). However we can now expect a nearly stoichiometric utilization of the carbon in the fermentation process (Kopke and Simpson, 2020). Obviating the reverse water gas shift reaction could also accelerate the kinetics of the overall conversion.

$$
\begin{aligned}
\Delta G_{\min } & =12 \times 257.1 \mathrm{~kJ} / \mathrm{mol}+24 \times 237.1 \mathrm{~kJ} / \mathrm{mol} \\
& =8.8 \mathrm{MJ} / \mathrm{mol}_{\text {dodecane }}
\end{aligned}
$$

Therefore, the practical energy input will be roughly $17 \mathrm{MJ} /$ $\mathrm{mol}_{\text {dodecane }}=1.5 \div 0.75 \times 8.8 \mathrm{MJ} / \mathrm{mol}_{\text {dodecane }}$ instead of $28 \mathrm{MJ} /$ mol that was employed in less efficient Fischer-Tropsch conversion. Moreover, the process now benefits from reaction conditions that involve near ambient pressures and temperatures instead of the high pressures and temperatures and low carbon utilization of a process that relies on Fischer-Tropsch chemistry. Because of the enhanced utilization of the carbon, this route applied to the $\mathrm{CO}_{2}$ produced by ethanol fermentation could produce almost $13 \%$ of the U.S. demand for jet fuel but would require inputting $17 \mathrm{EJ} /$ year in renewable electricity, which is about 3.2 times the $\sim 5.4 \mathrm{EJ} /$ year of noncarbogenic energy produced in the U.S.

Given a renewable and frugal source of $\mathrm{H}_{2}$ plus highly competent microorganisms maintained in a well-engineered reactor, one could even imagine using a combination of $\mathrm{CO}_{2}$ and $\mathrm{CO}$ as the source of carbon instead of $\mathrm{CO}$ :

$$
\begin{gathered}
\mathrm{CO}_{2}+\mathrm{CO}+5 \mathrm{H}_{2} \rightarrow \mathrm{CH}_{3} \mathrm{CH}_{2} \mathrm{OH}+2 \mathrm{H} 2 \mathrm{O} \\
\Delta \mathrm{G}_{\text {reaction }}=-115 \mathrm{~kJ} / \mathrm{mol} \text { Reaction } 9
\end{gathered}
$$

In that case the minimum input energy would be smaller because it would, again, be the organisms that would undertake the equivalent of the reverse water gas shift reaction to generate the carbon that reports to the product ethanol The stoichiometric coefficients are derived from Reaction 9.

$$
\begin{aligned}
\Delta G_{\min } & =6 \times 257.1 \mathrm{~kJ} / \mathrm{mol}+30 \times 237.1 \mathrm{~kJ} / \mathrm{mol} \\
& =8.7 \mathrm{MJ} / \mathrm{mol}_{\text {dodecane }}
\end{aligned}
$$

However, the practical energy would still be about 2 times larger, $\Delta G_{\text {practical }}=16 \mathrm{MJ} / \mathrm{mol}$ from the electrochemical overpotential and the penalty arising from the selectivity of the oligomerization process. The process would benefit again from near ambient reaction conditions (temperature, pressure), very effective utilization of the input carbon, and further from the elimination of the electrochemical production of some of the $\mathrm{CO}$. If this process were applied to the roughly $180 \mathrm{Mt} /$ year of $\mathrm{CO}_{2}$ produced in the refining of petroleum (U.S. Environmental Protection Agency, 2020) then it could satisfy about half the demand for jet fuel but would consume about 10 times the present amount of renewable electricity produced in the U.S. each year (53 EJ/year $\div 5.4 \mathrm{EJ} /$ year $)$.

\section{COMPARISONS WITH AVAILABLE AMOUNTS OF RENEWABLE MATERIAL AND ENERGY}

We compare the energy and mass requirements for producing the total U.S. jet fuel consumption in 2020 using the pathways discussed above. Some of the processes just discussed can benefit from direct application of renewable energy and all the processes require direct inputs of either renewable or waste carbon (Table 3). The second column of Table 3 presents the noncarbogenic energy input required to make a year's supply of sustainable aviation fuel for the U.S., either as the heat of combustion of the indicated feedstock or as the amount of renewable electricity needed to make the indicated the starting material from $\mathrm{CO}_{2}$. The fourth column of the table compares the mass of the indicated, noncarbogenic input required to make the 
TABLE 3 | Comparison of minimum and available input energies and masses required by processes that might make 0.45 Tmol/year of sustainable aviation fuel for the U.S. market.

\begin{tabular}{|c|c|c|c|c|}
\hline Process & $\begin{array}{c}\text { Basis: Required, renewable } \\
\Delta G_{\text {min }} \text { energy needed to } \\
\text { make SAF Available } \\
\text { noncarbogenic energy }\end{array}$ & $\begin{array}{l}\text { Electric generation and } \\
\text { capacity requirements to } \\
\text { meet electricity needs }\end{array}$ & $\begin{array}{l}\text { Basis: Required, renewable } \\
M_{\min } \text { Mass needed to make } \\
\text { SAF Available } \\
\text { noncarbogenic mass }\end{array}$ & Comment \\
\hline $\begin{array}{l}\text { Fischer-Tropsch, based on } \\
\text { autothermal gasification of } \\
\text { sustainably produced } \\
\text { biomass }\end{array}$ & $\begin{array}{l}8 \mathrm{MJ}_{\mathrm{th}} / \mathrm{mol}_{\text {dodecane }} \\
14.4 \mathrm{EJ} / \text { year as biomass } \\
\text { 16.5 EJ/year as biomass } \\
(=826 \mathrm{Mt} / \text { year } \times 20 \mathrm{MJ} / \mathrm{kg})\end{array}$ & & $\begin{array}{l}12 \mathrm{~mol}_{\mathrm{CH}_{2} \mathrm{O}} / \mathrm{mol}_{\text {dodecane }} \\
960 \mathrm{Mt}_{\text {biomass }} / \text { year } \\
826 \mathrm{Mt}_{\text {biomass }} / \text { year }\end{array}$ & $\begin{array}{l}\text { Assumes } 50 \% \text { energy and } \mathrm{C} \\
\text { efficiency for production of } \\
\mathrm{C}_{12} \mathrm{H}_{26} \text {, biomass }=\left(-\mathrm{CH}_{2} \mathrm{O}-\right)_{n} \\
\text { available mass from long term, } \\
\text { base case of the Billion Ton } \\
\text { Study }\end{array}$ \\
\hline $\begin{array}{l}\text { Fischer-Tropsch, based on } \\
\text { electrochemically sourced } \\
\text { synthesis gas ex } \mathrm{CO}_{2}\end{array}$ & $\begin{array}{l}9 \mathrm{MJ} / \mathrm{mol}_{\text {dodecane }} \\
12.2 \mathrm{EJ} / \text { year as electricity } \\
\text { 5.4 EJ/year (U.S. supply of } \\
\text { noncarbogenic electricity) }\end{array}$ & $\begin{array}{l}3,400 \text { TWh of generation } \\
390 \mathrm{GW} \text { of firm capacity or } \\
1200 \mathrm{GW} \text { of wind (assuming a } \\
\text { capacity factor of } 33 \% \text { ) }\end{array}$ & $\begin{array}{l}12 \mathrm{~mol}_{\mathrm{CO}_{2}} / \mathrm{mol}_{\text {dodecane }} \\
475 \mathrm{Mt}_{\mathrm{CO}_{2}} / \text { year } \\
43 \mathrm{Mt}_{\mathrm{CO}} / \text { year }\end{array}$ & $\begin{array}{l}\mathrm{CO}_{2} \text { from production of } 16 \text { billion } \\
\text { gal/year of ethanol. Assumes } \\
67 \% \text { energy efficiency and } 50 \% \\
\mathrm{C} \text { efficiency for production of } \\
\mathrm{C}_{12} \mathrm{H}_{26}\end{array}$ \\
\hline $\begin{array}{l}\text { "wood" }+0.55 \mathrm{O}_{2} \rightarrow \mathrm{CO}+ \\
2.4 \mathrm{H}_{2} \\
2 \mathrm{CO}+4 \mathrm{H}_{2} \rightarrow \mathrm{C}_{2} \mathrm{H}_{5} \mathrm{OH}+\mathrm{H}_{2} \mathrm{O} \\
6 \mathrm{C}_{2} \mathrm{H}_{5} \mathrm{OH} \rightarrow \text { jet fuel }\end{array}$ & $\begin{array}{l}8 \mathrm{MJ}_{\mathrm{th}} / \mathrm{mol}_{\text {dodecane }} \\
15 \mathrm{EJ} / \text { year as lignocellulosics } \\
16.5 \mathrm{EJ} / \text { year as biomass } \\
(=826 \mathrm{Mt} / \text { year } \times 20 \mathrm{MJ} / \mathrm{kg})\end{array}$ & & $\begin{array}{l}16 \mathrm{~mol}_{\mathrm{co}} / \mathrm{mol}_{\text {dodecane }} \\
770 \mathrm{Mt}_{\text {biomass }} / \text { year } \\
826 \mathrm{Mt}_{\text {biomass }} \text { year }\end{array}$ & $\begin{array}{l}\text { Assumes } 100 \% \mathrm{C} \text { efficiency in } \\
\text { the gasification and fermentation } \\
\text { and } 75 \% \mathrm{C} \text { efficiency in the } \\
\text { oligomerization }\end{array}$ \\
\hline $\begin{array}{l}\text { Oligomerization of ethanol, ex } \\
\text { fermentation of starches and } \\
\text { sugars }\end{array}$ & $\begin{array}{l}8 \mathrm{MJ}_{\mathrm{th}} / \mathrm{mol}_{\text {dodecane }} \\
\text { 7.2 EJ/year as cellulose } \\
\text { 12.4 EJ/year as lignocellulose }\end{array}$ & & $\begin{array}{l}3 \mathrm{~mol}_{\text {glucose }} / \mathrm{mol}_{\text {dodecane }} \\
360 \mathrm{Mt}_{\text {cellulose }} / \text { year } \\
550 \mathrm{Mt}_{\text {tcellulose }} / \text { year }\end{array}$ & $\begin{array}{l}\text { Assumes all sugar in } \\
\text { lignocellulosic feedstock ( } 2 / 3 \\
\text { cellulose) is available and does } \\
\text { not account for process energy }\end{array}$ \\
\hline $\begin{array}{l}\text { Oligomerization of ethanol, ex } \\
\text { waste gas from steel } \\
\text { production }\end{array}$ & $\begin{array}{l}8 \mathrm{MJ}_{\mathrm{th}} / \mathrm{mol}_{\text {dodecane }} \\
7.3 \mathrm{EJ} \text { as CO } \\
0.4 \mathrm{EJ} \text { as CO }\end{array}$ & & $\begin{array}{l}36 \mathrm{~mol}_{\mathrm{co}} / \mathrm{mol}_{\text {dodecane }} \\
650 \mathrm{Mt}_{\mathrm{co}} / \text { year } \\
28 \mathrm{Mt}_{\mathrm{CO}} / \text { year }\end{array}$ & $\begin{array}{l}\text { CO from use of metallurgical } \\
\text { coke; amount from US Energy } \\
\text { Information Administration }\end{array}$ \\
\hline $\begin{array}{l}\text { Oligomerization of ethanol, ex } \\
\text { electrochemically sourced } \\
\text { synthesis gas, ex } \mathrm{CO}_{2} \\
\text { and } \mathrm{H}_{2} \mathrm{O}\end{array}$ & $\begin{array}{l}\text { 8.8 } \mathrm{MJ}_{\mathrm{e}} / \mathrm{mol}_{\text {dodecane }} \\
\text { 8.5 EJ as electricity } \\
\text { 5.4 EJ/year }\end{array}$ & $\begin{array}{l}2,400 \text { TWh of generation } \\
270 \mathrm{GW} \text { of firm capacity or } \\
810 \mathrm{GW} \text { of wind (assuming a } \\
\text { capacity factor of } 33 \% \text { ) }\end{array}$ & $\begin{array}{l}12 \mathrm{~mol}_{\mathrm{CO}_{2}} / \mathrm{mol}_{\text {dodecane }} \\
340 \mathrm{Mt}_{\mathrm{CO}_{2}} \\
43 \mathrm{Mt}_{\mathrm{CO}} / \text { year }\end{array}$ & $\begin{array}{l}\text { Amount from } 16 \text { billion gal/year of } \\
\text { ethanol and fermentation } \\
\text { stoichiometry of } \mathrm{CO}_{2} / \mathrm{C}_{2} \mathrm{H}_{5} \mathrm{OH} \\
=1\end{array}$ \\
\hline
\end{tabular}

sustainable aviation fuel with its availability. The basis for those inputs derives from the stoichiometries and assumed energy efficiencies described above.

Both types of inputs would require almost all, or more than, the projected availability of those inputs to satisfy the growing demand for renewably-sourced jet fuel in the U.S. For example, the Fischer-Tropsch process based on electrochemically sourced synthesis gas from $\mathrm{CO}_{2}$ would require on the order of $87 \%$ of today's total electricity generation or the addition of $1170 \mathrm{GW}$ of on-shore wind capacity. In 2020, the U.S. has $126 \mathrm{GW}$ installed wind capacity. These are enormous electricity requirements which also require appropriate transmission infrastructure to deliver the electricity from the remote wind-sites to the load centers. While there may be enough production of lignocellulosic feedstock to source a year's consumption of aviation fuel in the U.S., its heating value is not high enough to feed a conventional FischerTropsch process.

Some combination of renewably sourced hydrogen plus carbon dioxide captured from a source less concentrated than the ethanol production of ethanol could supply the requisite material $\left(\mathrm{C}\right.$ and $\left.\mathrm{H}_{2}\right)$, albeit at a higher capital cost for the equipment needed to capture the $\mathrm{CO}_{2}$.
To further illustrate the mismatch between the needs of the aviation industry and the availability of noncarbogenic energy and waste or renewable carbon, consider the process discussed in Section 3.5 at the level of an individual facility (Figure 3). An ethanol fermentation plant that makes 100 million gallons per year is near the average size of the facilities in the U.S. (16 billion gallons/year $\div 200$ plants $=80 \mathrm{Mgal} /$ year/plant. By the stoichiometry of Reaction 5, such a plant would make $310 \mathrm{kt} /$ year of carbon dioxide. Electrochemically converting that $\mathrm{CO}_{2}$ and water into a synthesis gas will require a practical input of electrical energy of about $5 \mathrm{PJ}_{\mathrm{e}} /$ year $\left(=160 \mathrm{MW}_{\mathrm{e}}\right)$ and could make something like 10 million gallons per year of jet fuel. To provide a perspective on the size of existing non-carbon generation capacity it would vary from $14 \%$ of a typical nuclear plant or large hydro power plant to about $44 \%$ of a large wind farm, to $83 \%$ of a large solar farm (Figure 3).

Several options described in Table 3 do not require significant amounts of additional renewable electricity and do match the available resources of renewable carbon: Fischer-Tropsch Synthesis, oligomerization of ethanol produced either from fermenting cellulosic sugar or from synthesis gas made by gasification of biomass. However, 


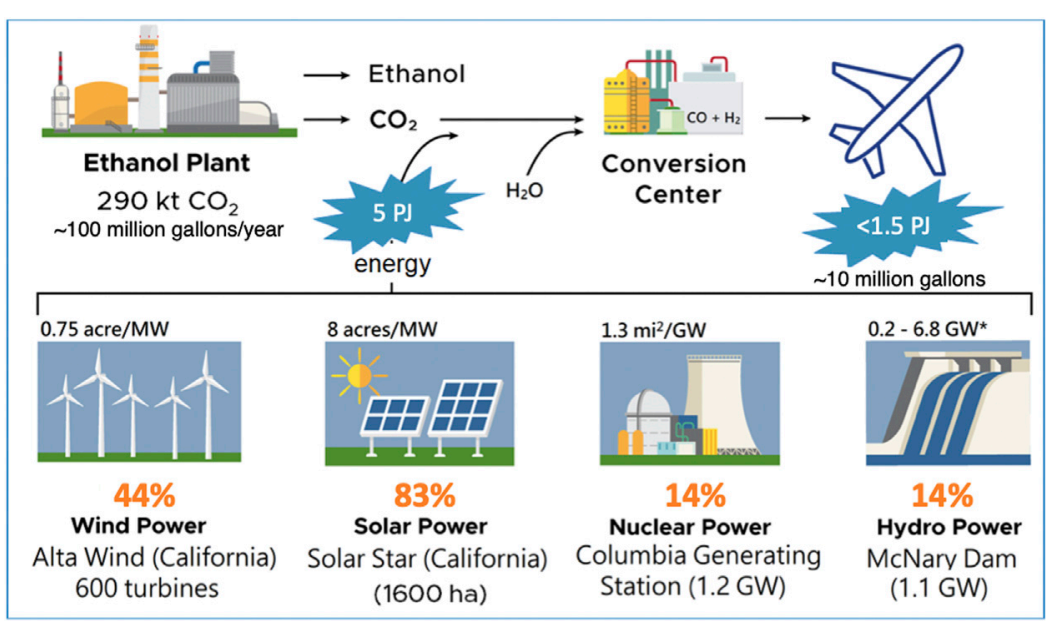

FIGURE 3|Summary process flow sheet for the example described in Section $\mathbf{3 . 5}$ along with the fraction of a grid scale electricity generating facility needed to power it.

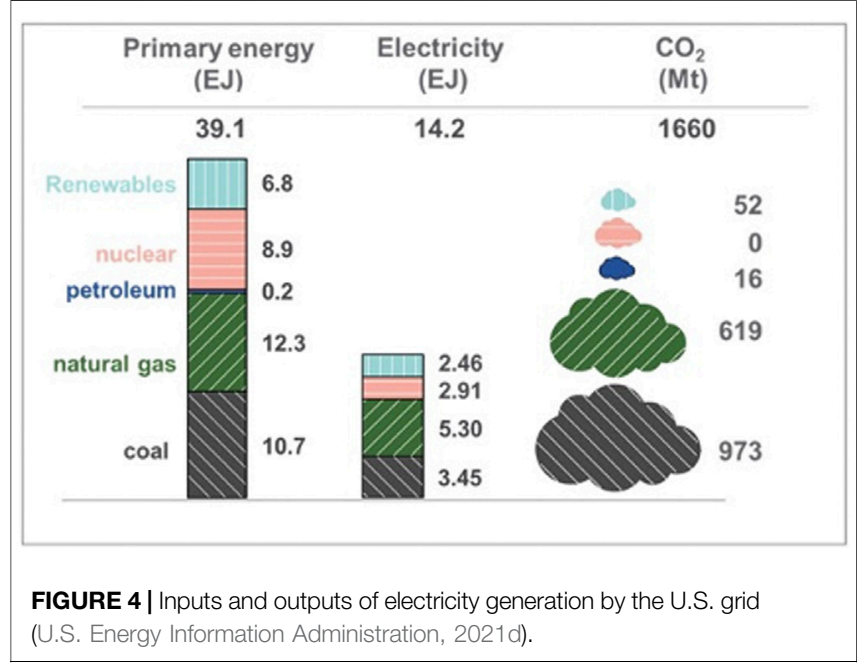

each raises a difficulty. We have already mentioned that fermenting cellulosic sugar is problematic. Gasification of biomass can, in principle, produce a synthesis gas whose $\mathrm{H}_{2} / \mathrm{CO}$ ratio permits carbon-efficient fermentation (Kopke and Simpson, 2020). In line with our previous assumptions, oligomerizing that ethanol into jet fuel would be $75 \%$ carbon efficient. In that case there may be sufficient renewable biomass to produce the 26.8 billion gallons of jet fuel currently employed in the U.S. However, meeting the projected growth in demand for jet fuel would strain the supply of biomass. Moreover, even though gasification is an old, well studied technology, it appears to be difficult to implement robustly at the scale that would be required here. The same issue arises when considering FischerTropsch synthesis starting with biomass-derived synthesis gas. Thus, there is no clear path forward: either there needs to be significant progress in gasifying biomass at scale or the introduction of significant amounts of renewable clean power.

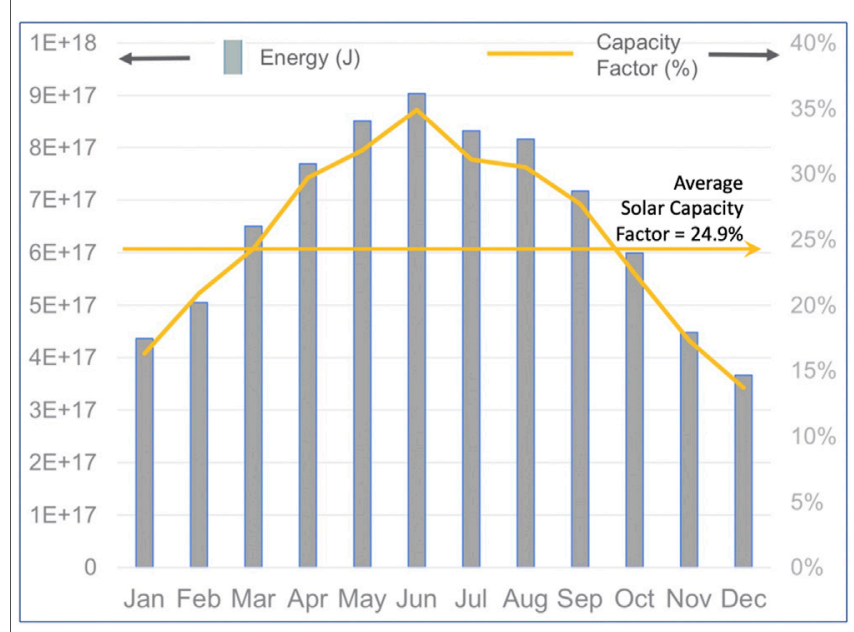

FIGURE 5 | Example of the variability of a renewable resource for generating power that might be used to produce SAF (U.S. Energy Information Administration, 2021b).

\section{POSITIONING SAF IN A SEQUENCE OF OPTIONS FOR MAKING THE TRANSPORTATION SECTOR MORE SUSTAINABLE}

The energy inputs listed in the second column of Table 3 are all near $10 \mathrm{EJ} /$ year. If that delivery rate of fuel or energy were converted to, or employed as, zero-carbon emission gridsupplied power then it could substantially displace the use of coal to generate electrical power and thus remove nearly a Gt/year of $\mathrm{CO}_{2}$ (Figure 4). Therefore, employing renewable or waste resources to first "clean the grid" by eliminating the combustion of fossil fuels for the generation of electricity would offer a larger, more immediate environmental benefit than would employing the resources to produce a noncarbogenic fuel for aviation 


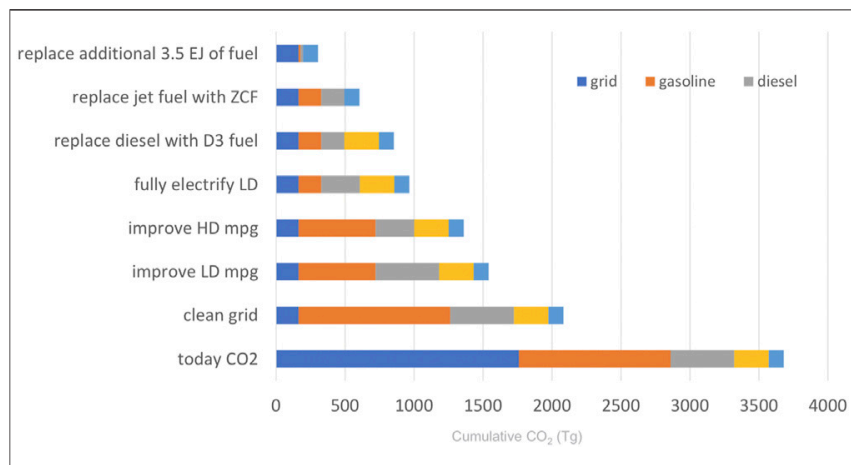

FIGURE 6 | A sequence of technical changes that offers a steady, rapid decrease in the $\mathrm{CO}_{2}$ footprint of transportation. Abbreviations: ZCF-net zero carbon fuel; D3-diesel fuel derived from a cellulosic feedstock; LD-light duty; HD-heavy duty; mpg-miles per gallon.

(removal of only $255 \mathrm{MT} /$ year (see Figure 2). Indeed, given that electricity is nearly fungible, first cleaning the grid is a prerequisite to using grid power for any of the electrochemical step in the production of SAF. Concurrent with dedicating renewable resources to powering the grid, there is a need to implement energy storage to buffer the variability of the resource (e.g., clouds, calm winds) or periodic (diurnal and seasonal) variability (Figure 5).

Again, from the perspective of overall efficiency, the first priority should be cleaning the grid by replacing fossil-fueled thermal plants with noncarbogenic generating capacity, followed by a succession of improvements in the utilization of the clean energy (Figure 6). The illustrated sequence displaces the dirtiest options as early as possible.

\section{CONCLUSION}

In the future, feedstocks that are the end products of combustion (e.g., $\mathrm{CO}_{2}, \mathrm{H}_{2} \mathrm{O}$ ) may be needed as a source of materials to make fuels. First, however, the renewable energy that would be required to upgrade those molecules would be better employed for upgrading carbon-containing feedstocks that do afford enthalpy of combustion (e.g., CO). In comparing systems, we appreciate that examining the energy use, the source of carbon, carbon conversion yields to desired products, and use of hydrogen are important in arriving at an optimal solution. Still, for the systems examined here, very large amounts of energy (more than twice what we have available

\section{REFERENCES}

Agricultural Marketing Resource Center (2018). Switchgrass. Available at: https:// www.agmrc.org/commodities-products/biomass/switchgrass (Accessed July 1, 2021).

Airlines for America (2021). A4A Climate Change Commitment and Flight Path. Available at: https://airlines.org/wp-content/uploads/2021/05/A4A- today) plus energy storage will be needed to generate quantities of fuel that will assist the aviation sector in meeting its environmental targets. Moreover, cleaning and stabilizing the grid must come first. Those improvements will require massive investments in renewable electric generation capacity such as off-shore and on-shore wind and solar, as well as massive amounts of energy storage to balance the daily and seasonal variability of wind and solar resources. We recognize that all the discussed options merit additional analysis and research to order them and to implement them for successful energy transitions and eventual deployment of solutions in the aviation sector that maximize carbon intensity reduction and sustainability. If they are to be deployed, they should be derisked in tandem with building the electrical power energy infrastructure. We believe that a sequencing, like that shown in Figure 6, will be critical and represents a novel contribution to this important discussion.

\section{AUTHOR CONTRIBUTIONS}

All authors listed have made a substantial, direct, and intellectual contribution to the work and approved it for publication.

\section{FUNDING}

This work was funded by the Bioproducts Institute at Pacific Northwest National Laboratory (PNNL) and Washington State University. PNNL is a multiprogram national laboratory operated for DOE by Battelle under Contract DE-AC05-76RL01830.

\section{ACKNOWLEDGMENTS}

The analyses and formulation of this paper benefited greatly from the inspiration, insights, and rigor of our colleague, John Holladay.

\section{SUPPLEMENTARY MATERIAL}

The Supplementary Material for this article can be found online at: https://www.frontiersin.org/articles/10.3389/fenrg.2021.765360/ full\#supplementary-material

Climate-Change-Commitment-Flight-Path-to-Net-Zero-FINAL-3-30-21. pdf (Accessed August 16, 2021).

Albert, J., Jess, A., Kern, C., Pöhlmann, F., Glowienka, K., and Wasserscheid, P. (2016). Formic Acid-Based Fischer-Tropsch Synthesis for Green Fuel Production from Wet Waste Biomass and Renewable Excess Energy. ACS Sustain. Chem. Eng. 4, 5078-5086. doi:10.1021/acssuschemeng.6b01531

ASTM International (2021). Standard Specification for Aviation Turbine Fuel Containing Synthesized Hydrocarbons, ASTM D7566-21. Available 
at: https://www.astm.org/Standards/D7566.htm (Accessed August 4, 2021).

Babcock and Wilcox Company (2015). CO Boilers for the Hydrocarbon Processing Industry. Available at: https://www.babcock.com/resources/ learning-center/co-boilers-for-the-hydrocarbon-processing-industry (Accessed August 12, 2021).

Brooks, K. P., Snowden-Swan, L. J., Jones, S. B., Butcher, M. G., Lee, G.-S. J., Anderson, D. M., et al. (2016). "Low-Carbon Aviation Fuel through the Alcohol to Jet Pathway," in Biofuels for Aviation (Cambridge: Academic Press), 109-150. doi:10.1016/b978-0-12-804568-8.00006-8

Chang, C. D. (2007). Methanol Conversion to Light Olefins. Catal. Rev. 26, 323-345. doi:10.1080/01614948408064716

de Klerk, A. (2016). "Aviation Turbine Fuels through the Fischer-Tropsch Process," in Biofuels for Aviation (Cambridge: Academic Press), 241-259. doi:10.1016/b978-0-12-804568-8.00010-x

Dry, M. E. (2004). "Chemical Concepts Used for Engineering Purposes," in FischerTropsch Technology (Amsterdam: Elsevier), 196-257. doi:10.1016/s01672991(04)80460-9

Gogate, M. R. (2019). Methanol-to-olefins Process Technology: Current Status and Future Prospects. Pet. Sci. Tech. 37, 559-565. doi:10.1080/ 10916466.2018.1555589

Graham, R. L., Nelson, R., Sheehan, J., Perlack, R. D., and Wright, L. L. (2007). Current and Potential U.S. Corn Stover Supplies. Agron. J. 99, 1-11. doi:10.2134/ agronj2005.0222

Green Car Congress (2021). Shell Invests in LanzaJet; AtJ Sustainable Aviation Fuel. Available at: https://www.greencarcongress.com/2021/04/20210407lanzajet.html (Accessed November 16, 2021).

Gruber, H., Groß, P., Rauch, R., Reichhold, A., Zweiler, R., Aichernig, C., et al. (2019). Fischer-Tropsch Products from Biomass-Derived Syngas and Renewable Hydrogen. Biomass Conv. Bioref. 11, 2281-2292. doi:10.1007/ s13399-019-00459-5

Handler, R. M., Shonnard, D. R., Griffing, E. M., Lai, A., and Palou-Rivera, I. (2015). Life Cycle Assessments of Ethanol Production via Gas Fermentation: Anticipated Greenhouse Gas Emissions for Cellulosic and Waste Gas Feedstocks. Ind. Eng. Chem. Res. 55, 3253-3261. doi:10.1021/ acs.iecr.5b03215

Hannula, I., Kaisalo, N., and Simell, P. (2020). Preparation of Synthesis Gas from $\mathrm{CO} 2$ for Fischer-Tropsch Synthesis-Comparison of Alternative Process Configurations. C 6, 55-77. doi:10.3390/c6030055

Hazel, D., and Bardon, R. (2008). Conversion Factors for Bioenergy. Available at: https://content.ces.ncsu.edu/conversion-factors-for-bioenergy (Accessed July $15,2020)$.

Holladay, J. E., Male, J. L., Rousseau, R., and Weber, R. S. (2020). Synthesizing Clean Transportation Fuels from $\mathrm{CO} 2$ Will at Least Quintuple the Demand for Non-carbogenic Electricity in the United States. Energy Fuels 34, 15433-15442. doi:10.1021/ acs.energyfuels.0c02595

IATA (2009). Working towards Ambitious Targets. Available at: https://www. iata.org/en/programs/environment/climate-change/ (Accessed August 4, 2021).

International Council on Clean Transportation (2019). CO2 Emissions from Commercial Avaition 2018. Available at: https://theicct.org/sites/default/ files/publications/ICCT_CO2-commercl-aviation-2018_20190918.pdf.

Köpke, M., and Simpson, S. D. (2020). Pollution to Products: Recycling of 'above Ground' Carbon by Gas Fermentation. Curr. Opin. Biotechnol. 65, 180-189. doi:10.1016/j.copbio.2020.02.017

Korberg, A. D., Mathiesen, B. V., Clausen, L. R., and Skov, I. R. (2021). The Role of Biomass Gasification in Low-Carbon Energy and Transport Systems. Smart Energy 1, 100006. doi:10.1016/j.segy.2021.100006

Kortlever, R., Shen, J., Schouten, K. J. P., Calle-Vallejo, F., and Koper, M. T. M. (2015). Catalysts and Reaction Pathways for the Electrochemical Reduction of Carbon Dioxide. J. Phys. Chem. Lett. 6, 4073-4082. doi:10.1021/ acs.jpclett.5b01559

Lamers, P., T. Avelino, A. F., Zhang, Y., D. Tan, E. C., Young, B., Vendries, J., et al. (2021). Potential Socioeconomic and Environmental Effects of an Expanding U.S. Bioeconomy: An Assessment of Near-Commercial
Cellulosic Biofuel Pathways. Environ. Sci. Technol. 55, 5496-5505. doi:10.1021/acs.est.0c08449

Lilga, M. A., Hallen, R. T., Albrecht, K. O., Cooper, A. R., Frye, J. G., and Ramasamy, K. (2017). US Pat. 9, 663416-B2.

Markets Insider (2021). Natural Gas (Henry Hub). Available at: https://markets. businessinsider.com/commodities/natural-gas-price (Accessed July 1, 2021).

Martinkus, N., Latta, G., Morgan, T., and Wolcott, M. (2017). A Comparison of Methodologies for Estimating Delivered forest Residue Volume and Cost to a wood-based Biorefinery. Biomass and Bioenergy 106, 83-94. doi:10.1016/ j.biombioe.2017.08.023

McAloon, A., Taylor, F., Yee, W., Ibsen, K., and Wooley, R. (2000). Determining the Cost of Producing Ethanol from Corn Starch and Lignocellulosic Feedstocks. Available at: https://www.nrel.gov/docs/ fy01 osti/28893.pdf.

MIT Department of Civil and Environmental Engineering (1999). Chemical Composition of Structural Steels. Available at: https://web.mit.edu/1.51/ www/pdf/chemical.pdf (Accessed July 29, 2021).

National Academies of Sciences and Medicine (2016). Commercial Aircraft Propulsion and Energy Systems Research. Available at: https://www.nap.edu/ catalog/23490/commercial-aircraft-propulsion-and-energy-systems-researchreducing-global-carbon (Accessed November 29, 2021).

Ostadi, M., Rytter, E., and Hillestad, M. (2019). Boosting Carbon Efficiency of the Biomass to Liquid Process with Hydrogen from Power: The Effect of $\mathrm{H} 2 / \mathrm{CO}$ Ratio to the Fischer-Tropsch Reactors on the Production and Power Consumption. Biomass and Bioenergy 127, 105282. doi:10.1016/ j.biombioe.2019.105282

Rakowski-Dubois, M., and Dubois, D. L. (2009). Development of Molecular Electrocatalysts for $\mathrm{CO} 2$ Reduction and $\mathrm{H} 2$ Production/Oxidation. Acc. Chem. Res. 42, 1974-1982. doi:10.1021/ar900110c

Reed, M., Van Bibber, L., Shuster, E., Haslbeck, J., Olson, S., and Kramer, S. (2007). Baseline Technical and Economic Assessment of a Commercial Scale FischerTropsch Liquids Facility (DOE/NETL-2007/1260). Available at: https://www.netl. doe.gov/sites/default/files/netl-file/Baseline-Technical-and-Economic-Assessmentof-a-Commercial.pdf.

Samavati, M., Santarelli, M., Martin, A., and Nemanova, V. (2018). Production of Synthetic Fischer-Tropsch Diesel from Renewables: Thermoeconomic and Environmental Analysis. Energy Fuels 32, 1744-1753. doi:10.1021/ acs.energyfuels.7b02465

Shahabuddin, M., Alam, M. T., Krishna, B. B., Bhaskar, T., and Perkins, G. (2020). A Review on the Production of Renewable Aviation Fuels from the Gasification of Biomass and Residual Wastes. Bioresour. Tech. 312, 123596. doi:10.1016/ j.biortech.2020.123596

Tock, L., Gassner, M., and Maréchal, F. (2010). Thermochemical Production of Liquid Fuels from Biomass: Thermo-Economic Modeling, Process Design and Process Integration Analysis. Biomass and Bioenergy 34, 1838-1854. doi:10.1016/j.biombioe.2010.07.018

U.S. Department of Energy (2016). 2016 Billion-Ton Report: Advancing Domestic Resources for a Thriving Bioeconomy, Volume 1: Economic Availability of Feedstocks. Available at: http://energy.gov/eere/bioenergy/2016-billion-tonreport.

U.S. Energy Information Administration (2019). Annual Energy Outlook 2019. Available at: https://www.eia.gov/outlooks/aeo/data/browser/\#/?id=12AEO2019\&cases $=$ ref2019\&sourcekey $=0$ (Accessed July 30, 2019).

U.S. Energy Information Administration (2021a). Annual Energy Outlook 2021: Electricity Generating Capacity. Available at: https://www.eia.gov/outlooks/ aeo/data/browser/\#/?id=9-AEO2021\&cases $=$ ref2021\&sourcekey $=0$ (Accessed June 25, 2021).

U.S. Energy Information Administration (2021b). Capacity Factors for Utility Scale Generators Primarily Using Non-fossil Fuels. Available at: https://www. eia.gov/electricity/monthly/epm_table_grapher.php?t=table_6_07_b (Accessed July 29, 2021).

U.S. Energy Information Administration (2021c). Ethanol Plant Production-Fuel Ethanol. Available at: https://www.eia.gov/dnav/pet/pet_sum_sndw_a EPOOXE_YOP_mbblpd_4.htm (Accessed August 8, 2021).

U.S. Energy Information Administration (20202019). Jet Fuel Consumption, price, and Expenditure Estimates. Available at: https://www.eia.gov/state/ 
seds/data.php?incfile=/state/seds/sep_fuel/html/fuel_jf.html (Accessed July 2, 2021).

U.S. Energy Information Administration (2021d). July 2021 Monthly Energy Review. Available at: https:/www.eia.gov/totalenergy/data/monthly/pdf/mer. pdf (Accessed July 29, 2021).

U.S. Energy Information Administration (2021e). Quarterly Coal Consumption and Quality Report - Coke Plants. Available at: https://www.eia.gov/coal/ production/quarterly/pdf/tes2p01p1.pdf (Accessed June 30, 2021).

U.S. Environmental Protection Agency (2010). Available and Emerging Technologies for Reducing Greenhouse Gas Emissions from the Petroleum Refining Industry. Available at: https://www.epa.gov/sites/default/files/201512/documents/refineries.pdf (Accessed August 8, 2021).

U.S. Environmental Protection Agency (2020). Greenhouse Gas Reporting Program (GHGRP). Available at: https://www.epa.gov/ghgreporting/ghgrprefineries\#trends-subsector (Accessed August 5, 2021).

U.S. Geological Survey (2020). Iron and Steel. Available at: https://pubs.usgs.gov/ periodicals/mcs2020/mcs2020-iron-steel.pdf (Accessed July 29, 2021).

Zhang, Y., Li, B., Li, H., and Liu, H. (2011). Thermodynamic Evaluation of Biomass Gasification with Air in Autothermal Gasifiers. Thermochim. Acta 519, 65-71. doi:10.1016/j.tca.2011.03.005

Zhu, J. Y., Zhu, W., Obryan, P., Dien, B. S., Tian, S., Gleisner, R., et al. (2010). Ethanol Production from SPORL-Pretreated lodgepole pine: Preliminary
Evaluation of Mass Balance and Process Energy Efficiency. Appl. Microbiol. Biotechnol. 86, 1355-1365. doi:10.1007/s00253-009-2408-7

Conflict of Interest: The authors declare that the research was conducted in the absence of any commercial or financial relationships that could be construed as a potential conflict of interest.

Publisher's Note: All claims expressed in this article are solely those of the authors and do not necessarily represent those of their affiliated organizations, or those of the publisher, the editors and the reviewers. Any product that may be evaluated in this article, or claim that may be made by its manufacturer, is not guaranteed or endorsed by the publisher.

Copyright $\odot 2021$ Male, Kintner-Meyer and Weber. This is an open-access article distributed under the terms of the Creative Commons Attribution License (CC BY). The use, distribution or reproduction in other forums is permitted, provided the original author(s) and the copyright owner(s) are credited and that the original publication in this journal is cited, in accordance with accepted academic practice. No use, distribution or reproduction is permitted which does not comply with these terms.

This was a work for hire and thus the copyright belongs to the operator of PNNL, namely, Battelle Memorial Institute. 